\title{
Energy and Rangelands: A Perspective
}

\author{
By Jerry L. Holechek and Mohammed N. Sawalhah
}

\section{On the Ground}

- Depletion of conventional oil and natural gas reserves coupled to rising world demand for fossil fuels will have major impacts on US rangelands and ranches over the next 30 years.

- Shale oil and gas are unconventional fossil fuels now being aggressively developed on US rangelands. Their development involves a larger physical footprint in terms of roads, drill pads, mining pits, and water disposal ponds than conventional oil and gas development, but their development techniques are improving in terms of extraction efficiency and reduction of adverse environmental impacts. Groundwater contamination is the biggest potential threat to ranchers from shale oil and gas development.

- US ranchers will likely experience continued rising prices for their livestock due to world farmland loss, increased human population, and rising affluency in Asian countries, but their production costs will also rise due to higher energy costs. Implementing management practices involving risk aversion and minimization of fossil fuel use will be important for their future success.

- Basic principles of range management such as control of grazing intensity, grazing timing, animal distribution, and mix of animal species can be modified for management of energy developments on rangelands.

Keywords: rangeland, fossil fuels, renewable energy, nuclear power, fracking, meat production.

Rangelands 36(6):36-43

doi: 10.2111/RANGELANDS-D-14-00033

(C) 2014 The Society for Range Management

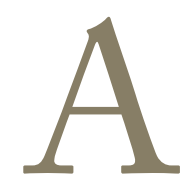

s we move into the 21st century, the biggest challenge confronting rangeland managers in the United States may be adjusting to rapidly rising energy costs and amelioration of adverse environmental impacts from energy developments. The United States has de- pleted its conventional or easy-to-extract oil and natural gas but has large reserves of unconventional fossil fuels (shale oil and gas) that are more difficult and costly to extract. Therefore it must and is aggressively developing both its renewable energy and its nonconventional fossil fuel resources that occur primarily on rangelands. The United States presently depends on fossil fuel (oil, natural gas, coal) for $83 \%$ of its energy and will still depend on fossil fuels for around $80 \%$ of its energy demand by 2040 according to projections by the US Energy Information Administration (USEIA). ${ }^{1}$ Between now and 2040 world energy consumption is projected to grow 44\% while US energy consumption is projected to grow 7\%., Even though there has been much hype regarding renewable energy sources (wind, solar, biomass), the USEIA projects they will only provide $12 \%$ of US and 15\% of world energy needs by 2040 while nuclear power might provide another $8-10 \% .{ }^{1,2}$ The USEIA projects the United States in the best case will probably still be importing $30-35 \%$ of its oil in 2040 even if shale oil and gas resources can be fully developed. ${ }^{1,2}$ The capability of shale resources to meet future energy demand has been contentious due to environmental concerns and uncertainty over their economic viability. However, out of necessity, the shale energy resources will be developed and this may have greater impact on rangelands than any other human activity. Unlike conventional oil and gas, shale reserves have low net energy yields and require a much larger and more invasive scale of extraction methods. ${ }^{3}$ In terms of land, the physical footprint of drill pads, roads, mining pits, water disposal ponds, and pipelines will likely be expanded many times over present levels (Fig. 1). ${ }^{3}$ Half or more of the shale energy resources in the United States occur on rangelands. This also applies to renewable energy sources such as wind, solar, and biomass. Aggressive development of shale and renewable energy sources in the United States necessitates that range managers and ranchers develop an understanding of both the economic and environmental aspects of this rapidly expanding rangeland use. Our objective in this article will be to examine present and future energy development approaches in the United States with implications for rangelands, range managers, and ranchers, with an emphasis on shale oil and gas resources.

\section{History of Energy Use}

Abundant, low-cost energy provides the foundation for our modern heavily industrialized, globalized world economy. ${ }^{4-7}$ 


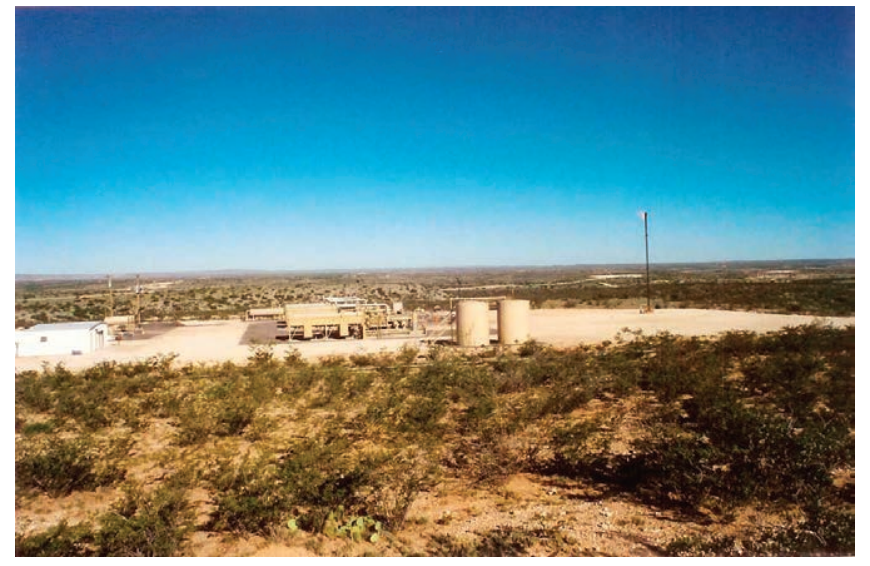

Figure 1. Rangeland in southeastern New Mexico impacted by roads, pipelines, and pumping stations from oil and gas development.

During most of the past 10,000 years leading to modern civilization, humans depended heavily on renewable energy in the forms of wood, wind, waterfalls, dams, human labor, and draft animals to meet basic energy needs. Human numbers were suppressed to well under a billion people compared to 7.2 billion people now because only a low level of productivity was possible from the renewable energy sources that were in use. The major improvement in human living conditions, increased life expectancies, and rapid population growth that have occurred over the last 200 years are closely tied to discoveries and inventions that enabled switching from renewable energy sources (biomass, wind, water) to fossil fuels, beginning with coal. Although coal has received limited use as an energy source for over 2,000 years, a technological breakthrough in 1712 caused its relative importance to rapidly increase. This involved development of the first successful steam engine by Thomas Newcomen in Great Britain for pumping water out of coal mines, which drastically increased coal accessibility. ${ }^{8}$ The steam engine could also be powered by coal. Rapid refinements in the steam engine during the late 1700s lead to development and use of steamboats and locomotives, first in Britain followed by the United States in the 1815-1830 period that revolutionized world transportation. Long-distance travel times were cut by $70 \%$ to $80 \%$ and much larger quantities of goods could be transported.

The next major energy advance involved the internal combustion engine. Various forms of internal combustion engines had been invented prior to the 1800s but a well-suited fuel source was lacking. This changed in the 1870s when kerosene refined from oil became the primary fuel for lamps. It was soon recognized that gasoline, a dangerous, volatile byproduct of oil refinement for kerosene, was the ideal fuel for internal combustion engines. ${ }^{8}$ Automobiles powered by internal combustion engines using gasoline quickly became a common form of transportation after 1910. Henry Ford's automobile refinements and his development of mass production assembly line manufacturing techniques in 1908 played a key role in the conversion from horses to cars for individual transportation in the 1910-1920 period. In the 1920s tractors replaced draft animals on American farms as a power source to pull implements such as plows, disks, harrows, and combines. The US economy converted from using primarily renewable energy and coal to being based on oil as the primary energy sources in the $1920 \mathrm{~s}^{8}{ }^{8}$ Both worldwide and in the United States, oil is still the primary energy source. In the United States, oil provides about 37\% of our energy compared to $34 \%$ worldwide. ${ }^{1,2}$ Natural gas (25\%) followed by coal (21\%) are our second and third most important energy sources. Worldwide, coal is second in importance (27\%) and natural gas is third (21\%).

The most disturbing aspect of our modern highly complex, industrialized, globalized society is that it depends so heavily on oil, a nonrenewable resource that will be greatly diminished within 40 years. We recognize global warming as a secondary major problem tied to fossil fuel use. Oil is not only the primary energy source for our transportation system but it also is the key component of plastics, pesticides, herbicides, asphalt, pharmaceuticals, lubricants, waxes, and petrochemicals that are now essential in our everyday life. ${ }^{9}$ Some other products incorporating oil include detergents, paint, shoes, tires, computers, diapers, and fertilizers. Without oil the unprecedented increase in human population, lifespan, material comfort, and ease of transportation never would have occurred.

\section{Oil Is the Superior Energy Source}

Because of its potency, ease of handling, ease of transport, and ease of extraction, oil is an overwhelmingly superior source of energy, with coal and natural gas in second and third place. ${ }^{5,6,10}$ From a practical standpoint, a horse laboring a standard 40-hour week would have to labor for more than a year to produce the energy in a barrel of oil. ${ }^{10} \mathrm{~A}$ fit human can do about one-tenth the labor of a horse. Through use of oil, it is estimated Americans on average have the equivalent of 80 slaves working $24 / 7 .^{8}$

\section{The EROI Concept}

The most commonly used and easily understood comparative measure of energy potency is the energy output to input ratio. Commonly referred to as the energy return on investment (EROI), it is the ratio of the amount of usable energy acquired from a particular energy source to the amount of energy expended to obtain that energy resource. ${ }^{6}$ If an energy resource has an EROI of one or less, it is not economically viable as there is no net energy gain from its extraction. Historically human societies have tried to maximize their energy gain using minimal expenditure of effort. In other words, the more potent, easily harvested or extracted energy sources are almost always used first rather than conserved. In the case of fossil fuels (oil, coal, natural gas), this has been especially true. Depletion of the more easily extracted conventional oil is the reason why oil prices have been in an uptrend since 2000 and will likely rise much more quickly during the next 30 years than any time in the past. ${ }^{5,6}$ 
Now we will briefly review the EROI history of conventional oil on which the tremendous progress and prosperity of the United States has been based. Dr Charles A. S. Hall, a professor at State University of New York, is considered a foremost authority on the EROI concept. ${ }^{6}$ His research has evaluated comparative EROIs of different energy sources, the change in the EROI of oil and gas extraction through time, and how the economy is impacted by changing energy EROI. In 1930 oil had an EROI of near 100 compared to 30 in 1970, 16-18 in 2000, and 13-15 now. This descent is due to oil becoming more difficult to find and the remaining oil being more costly to extract. The foundation for America's ascendance in prosperity has been abundant, cheap energy, primarily in the form of oil. $3,4,6$

In the period from 1930 to 1960, large reserves of conventional oil were found throughout the world but new finds have greatly diminished since the 1970s. ${ }^{3,5,6}$ We must increasingly invest more energy per unit return, which is causing growing concern about the sustainability of our progress. If the EROI of our combined energy sources drops from near 13-15 now to perhaps 5-7 within the next 20-30 years, the world's human population could be extremely challenged to meet basic needs (food, transportation, heat, material goods). ${ }^{5,6}$ The big problem is that alternative energy sources to oil have either low EROI values, low abundance, or both. Standard (conventional) light sweet crude oil that naturally flows from below-ground wells presently has an average EROI of 20, whereas that of natural gas is 10 . Coal is near 30 but expanded use of coal will exacerbate problems from carbon emissions and exacerbate depletion of higher-quality coal. Just like oil, the EROI declines as the more easily extracted reserves of coal and natural gas are depleted. Lower-grade unconventional substitutes such as shale oil, shale gas, tar sands, and deep-water oil must increasingly be used as replacement for conventional oil and gas. ${ }^{3,5,6,7}$ Shale oil and tar sands on average are estimated to have an EROI near 5. In regard to renewable energy alternatives, wind, solar, and bio-fuels are all greatly inferior to oil, natural gas, and coal in EROI. Solar and wind have EROIs between 3 and 8 depending on various factors such as siting, materials used, and labor inputs. ${ }^{6}$ Corn ethanol at best has an 1.3 EROI, whereas sugarcane is better at 1.7. Hydropower has an EROI of almost 100 but the suitable sites for dams are limited and most sites have been developed. Nuclear power, with an EROI of 15, can be a viable substitute for fossil fuels in electricity generation but it has constraints of safety, construction costs, limited uranium ore, and high water requirements. ${ }^{6,11}$

\section{Unconventional Oil Resources}

Due to recent breakthroughs in extraction involving fracking and horizontal drilling in combination, oil shale has become one of the most promising replacements for our dwindling conventional oil reserves. There is no doubt that the United States has abundant oil shale reserves. In the United States, total technically recoverable oil reserves are near 200 billion barrels which should meet our oil needs for $30-35$ years at current use rates. ${ }^{1-3}$ Conventional oil reserves account for roughly $20 \%$ of these reserves, oil shale about $58 \%$, and other sources, such as offshore/deep-water, about $27 \%{ }^{1,2}$ By some estimates US total oil shale reserves might be five to 10 times those considered recoverable but some major breakthroughs in extraction methods along with drastically higher oil and gas prices will be needed to make them economically viable., , $^{3,6}$

In actuality, there are two types of oil shale. This is poorly understood and causes much confusion about the long-term adequacy of our oil reserves. Type 1 oil shale (commonly called shale oil or tight oil) involves rock formations that hold actual oil, whereas type 2 oil shale involves rocks holding kerogen, which is a precursor to oil requiring expensive processing. ${ }^{12}$ The oil shale in Texas, North Dakota, Montana, and up into Canada is mostly high-grade type 1 , whereas the low-grade type 2 is abundant in Utah, Wyoming, and Colorado.,12 Total US oil needs might be met for 5 years with type 1 shale oil and another 18 years may be provided by type 2 oil shale if extraction becomes economically feasible.

Going back to the 1960s, repeated attempts have been made to develop type 2 oil shale resources but invariably these endeavors were suspended due to lack of profitability. ${ }^{6}, 12$ Even under high oil prices, the various costs of extraction and processing have made type 2 oil shale operations unprofitable. This is explained by a low EROI, varying from 1.5 to 5 . Remote areas of Utah, Colorado, and Wyoming have the best oil shale deposits but lack of infrastructure and water in these areas are major hindrances to their development.

On the positive side, shale oil development has been reducing US dependence on oil imports since 2008. The United States is now importing about $35 \%$ of its oil, compared to almost $60 \%$ in $2007 .{ }^{1,3}$ The reduction in US dependence on foreign oil is explained by an $11 \%$ drop in oil consumption between 2007 and 2013 (20.7 million barrels per day [mbd] vs. $18.6 \mathrm{mbd}$ ) and a $50 \%$ increase in oil production. Most of the production increase has come from shale oil development made possible by newly improved fracking and horizontal drilling techniques coupled with higher oil prices (over $\$ 90$ per barrel). The USEIA projects that in 2040 the United States will be using roughly the same amounts of oil as in 2013 (18.6 mbd) and importing 30-35\%. ${ }^{1,2}$ However, some energy experts consider these estimates overly optimistic.,12

\section{Rising Oil Production Costs}

The problem over the next 20 years is not absolute depletion of oil but rather rapidly rising costs of oil production. ${ }^{3,6,7}$ During most of the oil age that began about 1920 when automobile use become widespread, oil could be produced at under $\$ 5$ per barrel, inflation adjusted. ${ }^{6}$ Even though there were some oil supply shocks in the 1970s due to unrest in the Middle East, oil remained cheap to produce until the end of the 1990s. However, starting in 2000, depletion of conventional oil in conjunction with rising costs for exploration, drilling, infrastructure, and transport caused oil prices to begin increasing., ${ }^{5,6}$ Presently the average worldwide cost of producing a barrel of conventional 
oil is near $\$ 35$ to $\$ 40$, which is about four times that in the 1990s. ${ }^{6}$ Unconventional oil (shale oil, deep-water oil, tar sands) costs about $\$ 80$ to produce averaged across sources. Very importantly, these costs are rapidly rising. ${ }^{6,13}$ In the United States, about $50 \%$ of oil production now comes from unconventional sources. ${ }^{3}$ Costs for producing a conventional barrel of oil are rising at around $7 \%$ per year compared to $11 \%$ to $13 \%$ per year for unconventional oil. ${ }^{14,15}$ Unless breakthroughs occur that contain or lower these costs, oil price increases will escalate as conventional oil reserves are depleted and global demand expands. ${ }^{5-7}$ In the 1990 s oil prices averaged about $\$ 16$ per barrel compared to $\$ 95$ per barrel in 2013. ${ }^{1,3}$ By 2020 oil prices could be $\$ 250-300$ per barrel or more due to rising oil production costs and coupled to rising world oil demand. ${ }^{16}$

\section{World Oil Demand and Supply}

The other side of the oil equation is world demand. In the United States, improvements in vehicle fuel efficiency and reduction in miles traveled have dropped oil demand from 20.7 mbd in 2007 to $18.6 \mathrm{mbd}$ in 2012.,3 It is hoped that US oil demand can be contained at 18-19 mbd for the next 25 years through improved car mileage, use of electric cars, and other energy efficiency measures. However, worldwide oil demand is growing about $1.5 \%$ per year. Present world oil demand of 92-93 mbd will probably increase to $100 \mathrm{mbd}$ in 2020, 115 mbd in 2030, and $130 \mathrm{mbd}$ in 2040 if the supply is available and affordable. The main driver in oil consumption is China with its recent (2005-2013) rate of increase at 7\% per year but its future (2014-2030) rate of increase projected at 3\% per year. ${ }^{2}$ Increased oil use is essential for industrialization and major improvements in living conditions in developing countries. ${ }^{4-7}$ About two-thirds of the world's human population lives in developing countries that will need to substantially increase their oil use to keep up with population growth and develop their economies. It is projected that the world human population will increase about 30-35\% from 7.1 billion people to $9-10$ billion by $2050 .{ }^{17,18}$ More people desiring a better life will accelerate fossil fuel depletion in the future compared to past decades unless big breakthroughs occur that enable a large increase in renewable energy production and reduce the costs of extracting unconventional oil.

Declines in world oil discovery and diminished oil exports by key suppliers are a growing problem. ${ }^{7,14,15}$ Currently about three barrels of oil are being consumed for every new barrel of oil found. ${ }^{6}$ The oil that is being found is mostly in places where extraction is quite costly, such as deep in the ocean, in arctic areas, and remote, politically unstable countries lacking in infrastructure. ${ }^{3,6,7}$ Nearly all the big oil fields have been discovered and are being rapidly depleted. More difficult and complicated oil extraction techniques are needed on the newer, smaller, interior fields. In the 1995-2005 period, the oil industry spent \$2.4 trillion to expand oil production by $16 \%$ but oil production was flat under this same level of spending in the $2005-2010$ period. ${ }^{13,15}$

Total remaining extractable oil in the world is estimated at between one and three million barrels with one trillion barrels already used. ${ }^{6}$ The remaining oil will last somewhere between 30 years and 80 years depending on rate of extraction and development of improved extraction technologies. Peak conventional oil production may have been reached in 2006 at 74 mbd., 5 However, increased demand during the last 7 years has been met through aggressively developing unconventional oil and accelerated extraction of remaining conventional oil. Presently the Middle East provides half of oil exports, former Soviet Union counties (primarily Russia) provide $22 \%$, West African countries provide $12 \%$, and $16 \%$ is provided by other countries (mostly Venezuela, North Africa, Canada). 1,2 Primary consumers of oil exports are Europe, the United States, Japan, China, and India. The global crude oil surplus capacity is about $2-4 \mathrm{mbd}$ (92 mbd consumption) but within 3-5 years there may be no surplus. Several major oil exporters are consuming more of their oil, which reduces their capability to meet growing demands from importers. ${ }^{7}$ As an example, oil available for export by Saudi Arabia has declined by about $40 \%$ over the last 10 years. Several countries, such as China and Indonesia, that were once oil exporters are now oil importers with rising demand. Mexico will soon transition from oil exporter to importer. Geopolitical tensions add to the probability of a major global oil shock over the next 5 years. Therefore it is critical for the United States to minimize its oil imports, especially from outside of North America. This means aggressive development of shale oil, shale gas, renewable energy sources, and nuclear power along with increasing energy efficiency and conservation.

\section{Status of Shale Oil and Gas Development}

Presently, US crude oil production is about 50\% above its 2008 low due in large part to shale oil development. ${ }^{1,3}$ Shale oil now comprises about $20 \%$ of US oil production. ${ }^{3}$ Two plays, the Bakken (North Dakota, Montana) and Eagle Ford (South Texas), account for over $80 \%$ of shale oil production with another 19 plays accounting for the remainder. ${ }^{3}$ It is generally overlooked that highly productive plays like the Bakken and Eagle Ford are uncommon. Production decline rates are high for shale oil wells, with drops of near $65 \%$ the first year and $90 \%$ or more after 5 years being typical. ${ }^{3}$ This necessitates large-scale establishment of new wells just to maintain production. In the combined Bakken and Eagle Ford plays, about 6,000 wells are needed to sustain production, with 1,542 new wells needed annually to offset declines. ${ }^{3}$ Overall, about $40 \%$ of production must be replaced annually to maintain output. ${ }^{3}$ Because current drilling rates are well above this level, production is growing rapidly. However, the number of drilling locations is finite. Under the current rate of drilling, it is a major concern that US shale oil production will peak in the 2016-2020 period and then decline. ${ }^{3,19}$ This could cause another spike in oil prices as in 2008 with serious consequences for the US economy.

\section{Shale Gas}

Since 2008 shale gas production has rapidly increased. It now accounts for $40 \%$ of US natural gas production. ${ }^{1,3}$ The 
shale gas increase has more than compensated for declines in conventional gas production. The expansion in shale gas production has caused optimism that natural gas in combination with nuclear power can compensate for oil depletion. ${ }^{10}$ Beginning in 2006, new horizontal drilling and fracking technology made it economically feasible to tap shale gas reserves. ${ }^{1,3,19,20}$ A major boom occurred in purchase and development of shale gas leases that has created a temporary glut of natural gas in the United States. ${ }^{19,20}$ This is because lease agreements typically specify immediate gas development regardless of profitability. ${ }^{3,20}$ The majority of leases have been unprofitable because decline rates are rapid (80\% or more in 3 years) for most wells, with only about $20 \%$ being sweet spots with high amounts of gas. ${ }^{3,19,20}$ Another low-price factor is that natural gas is a by-product from shale oil development with virtually no added production cost. ${ }^{3}$ This source of gas is the main reason natural gas prices in the United States have been suppressed in the $\$ 2.50-5.50$ per million metric British thermal units (MMBTU) range since 2009. In the 2000-2009 period, US natural gas prices averaged $\$ 5.26$ per MMBTU, going above $\$ 10$ per MMBTU in 2006 and 2008.,20 In Europe natural gas sells for \$10-12 per MMBTU. Natural gas prices would be substantially higher in the United States if it could be easily transported to overseas markets as oil is. However, progress is now being made in terms of facilities for US export of liquefied natural gas. This will undoubtedly increase US natural gas prices if Congress allows gas exports.

In the news media, natural gas is being heavily promoted as the solution to the United States' energy problems because we are said to have almost unlimited supplies, it has a high EROI (near 10), it burns much cleaner than oil, and there is no sulfur or mercury contamination as with coal. In reality, proven reserves of natural gas including shale are about 60 years worldwide and 21 years in the United States, ${ }^{1,3,19}$ making some energy experts much less optimistic. ${ }^{3,19,20}$ Because of improving technology to extract shale deposits, it is believed by some optimists there is enough natural gas to supply the United States for 110 years. In reality, both the extent of supply and capability to extract shale gas resources is highly uncertain. ${ }^{1}$ If the United States switches to natural gas for transportation and/or begins exporting natural gas, reserves could be exhausted within 15 years. ${ }^{3,19}$ If shale oil production along with by-product natural gas starts declining within the next 5 years, natural gas prices will likely double or more from present levels. This is because, outside the easy-to-get locations, costs to produce shale gas might typically be in the \$8-9 MMBTU range. ${ }^{21}$ Within 5-10 years, the easy-to-get shale gas will have been mostly extracted. ${ }^{3,19}$ A drastic increase will be needed in new wells and infrastructure to keep supplies expanding. To maintain output, $30 \%$ to $50 \%$ of shale gas production must be replaced annually with more drilling. ${ }^{3,19}$ All this drilling could necessitate natural gas prices above \$9 MMBTU, which will constrain economic growth. Natural gas prices above $\$ 8$ MMBTU cause serious hardship for consumers. ${ }^{12}$

\section{Environmental and Economic Impacts from Shale Oil and Gas Development}

So far we have focused on the rationale and need to develop shale energy resources. However, there has been major resistance and pushback to shale development in some eastern states and western localities. ${ }^{3,20}$ Shale oil and gas extraction and processing may involve major impacts to water, air, esthetic, and wildlife values over extensive landscapes. ${ }^{3,20}$ Detailed studies examining the environmental impacts of shale development on western rangelands are presently lacking but needed.

The biggest environmental concerns with shale energy developments involve water contamination, followed by water depletion. ${ }^{3,20}$ The Energy Policy Act of 2005 specifically exempts fracking from the environmental safety requirements of the Safe Drinking Water Act, the Clean Air Act, and the Clean Water Act. Roughly 1\% of fracking fluid involves chemicals and the rest is water. ${ }^{20}$ Fracking recipes vary somewhat depending on the shale characteristics and whether gas or oil is involved but routinely include potassium chloride, hydrochloric acid, citric acid, ethylene glycol, and other chemicals. Because some of the chemicals are toxic and/or carcinogenic to humans, a potential hazard is that they may leak out of well casings into groundwater aquifers. Shale formations generally occur below groundwater aquifers. So far, formally verified water contamination from fracking operations has been lacking but there have been citizen complaints. ${ }^{20,22}$ The US Environmental Protection Agency (EPA) will soon release a major report on this issue. Following fracking, the recovered wastewater typically receives some kind of purification treatment and is injected into old wells or stored in ponds lined with polyethylene.

Large quantities of water are required for fracking operations. ${ }^{20}$ About four to five million gallons of water are needed to frack a well on average, but up to 10 million gallons are needed in some cases. A well may be fracked 10 times or more. In the eastern United States, the amount of water used in fracking generally involves $2 \%$ or less of overall consumption, so it is not a major issue. In contrast, in the arid West, the water requirements for fracking relative to overall consumption and availability could become a major issue, especially on public lands.

Although there have been several anecdotal claims of environmental damage and health effects on humans, wildlife, and livestock from fracking operations, no definite conclusions can be drawn until the EPA issues its report. However, there is little doubt that large-scale expansion of shale energy development will leave some level of physical footprint on rangelands in roads, drill pads, pipelines, and mining pits. ${ }^{3,20}$ In certain areas, increased earthquakes are another potential problem of fracking operations. The reader is referred to Heinberg and Hughes for more detailed evaluations of shale energy development on the environment. ${ }^{3,20}$

Major progress is occurring in making fracking more environmentally friendly or "greener." ${ }^{23}$ A growing number of energy development companies are pioneering technological improvements such as gelled fluids to replace water in frack- 
ing treatments that allow operators to recycle water, reducing fresh water use; powering fracking operations with natural gas instead of diesel, thereby cutting fuel costs and emissions; improved treatment of wastewater; and improved plugging of fracking sites to reduce methane leaks. ${ }^{23}$ Horizontal drilling improvements are minimizing the number of large pits and roads needed in oil extraction. In combination, various new technologies have the potential to substantially lower the physical footprint of future oil and gas development in terms of roads, mining pits, water disposal ponds, and drill pads.

Fracking has definitely benefitted the US economy, although the longer-term environmental costs of shale oil and gas development remain uncertain. ${ }^{24}$ It has created thousands of jobs, provided desperately needed revenue for many local communities and states, provided a major source of income to many ranchers and farmers, and given households and businesses a reprieve from rising energy costs. Many economists consider shale oil and gas development the cornerstones of the revival of the US economy since 2009.

\section{Status of Renewable Energy Development}

Although much progress is being made in development of renewable energy sources (primarily wind, solar, biomass), so far there have been no major breakthroughs that will drastically reduce our dependence on fossil fuels. The USEIA ${ }^{1}$ projects total renewable energy will provide $12 \%$ of US total needs in 2040 compared to $9 \%$ now, although some energy experts believe $20 \%$ to $30 \%$ is possible. ${ }^{25}$ Fossil fuels will probably provide about $80 \%$ of energy needs in 2040 vs. $82 \%$ now, based on USEIA estimates. ${ }^{1}$ Nuclear power is projected to remain constant, accounting for $8 \%$ of total US energy consumption. Wind and biomass will account for most of the $3 \%$ increase expected in the importance of renewable energy. We will briefly evaluate the status of nuclear power but refer the reader to USEIA reports for detailed information on the status of renewable energy. ${ }^{1,2}$

\section{Nuclear Power}

Nuclear power is considered by many energy experts to be the fuel of the future because it can potentially provide the tremendous quantities of energy needed by an increasingly more populated and electronic-dependent world. ${ }^{10}$ The positive and negatives of nuclear power in a rangeland context are reviewed in detail by Holechek, from which we will summarize. $^{26}$

Advocates of nuclear power emphasize it has a high EROI (near 15), it creates virtually no atmospheric pollution, it does not have an intermittency problem like wind and solar, it is generally cheaper than wind or solar, and it requires much less land than wind, solar, or biomass. ${ }^{10,25}$ This last advantage has high relevance to rangelands. Land requirements for nuclear power are only about $2-3 \%$ of that needed for wind power, $12-13 \%$ of that needed for solar power, and well under $1 \%$ of that needed for corn ethanol production. ${ }^{27}$ Actually, corn ethanol production is the most land-intensive of all en- ergy alternatives. In this same study, it was found that wind power requires about four times more land than natural gas and seven times more land than coal per unit energy output.

Even though nuclear power has many advantages and shows more potential to replace fossil fuels than other alternatives, it also has major drawbacks that include high plant construction cost, high water requirements for cooling purposes, hazardous waste disposal problems, and major concerns over human health and safety. ${ }^{8,11}$ Because only areas with consistent annual water surpluses are suitable construction sites, nuclear power is not viable for many parts of the world. Both uranium availability and cost will constrain nuclear power development if it is widely used to replace fossil fuels. ${ }^{11}$ Even though much progress has been made in improving the safety of nuclear power plants, the Japan Fukishima nuclear disaster in 2011 has caused several developed countries, including the United States, Japan, European Union, and Australia to turn away from nuclear power.

\section{Range Livestock Production and Energy}

Since 2009, rising energy costs associated with oil depletion have had a major impact on rangeland livestock producers. Meat prices have significantly increased but so have production costs. In the 2004-2014 period, cattle prices (based on steer calves) have nearly doubled ( $\$ 1.10$ /pound in 2004 , $\$ 2.05$ / pound in 2013) while total ranching costs increased about 68\% based on surveys of New Mexico ranches. ${ }^{28}$ As specific examples, prices for protein supplements increased $116 \%$ while hay prices increased $75 \%$. Vehicle operation and livestock hauling costs increased $65-70 \%$. Fence costs were up 60\%.

In 2004 most New Mexico ranches suffered large financial losses (\$83 per animal unit) whereas in 2013 most had small profits ( $\$ 30$ per animal unit). ${ }^{28}$ Increasing cattle prices are now more than offsetting rising ranch costs. In 2014 (early spring), cattle prices are up about 40\% over those in 2013. The beef cow herd in the United States is at the lowest level since the early 1950s due to extended drought in the Southern Great Plains and California and a severe winter in the Northern Great Plains.

Surveys by agricultural economists at New Mexico State University indicate ranchers have adopted risk aversion management strategies involving light-conservative stocking and minimal use of supplemented feeds to cope with climatic adversity and rising costs. ${ }^{28}$ Based on our analyses of these ranch surveys stocking levels on New Mexico ranches during the past 10 years have averaged about $60 \%$ of those in the 1980s and 1990s. ${ }^{28}$ Basically, New Mexico ranchers have become oriented toward risk aversion. These risks fall into categories of climatic, biological, financial, and political as defined by Holechek and associates. ${ }^{29}$ Ranchers are learning that management of these risks are more important to success than maximizing their returns during periods when climatic conditions and livestock prices are favorable.

Strategies for rangeland livestock producers under future conditions of increasing energy costs and climatic volatility 
are discussed in detail by Holechek. ${ }^{26}$ Conservative stocking, use of highly adapted livestock, targeted grazing, and use of behavioral knowledge to efficiently use forage resources are key components of the strategies he recommends. Herding can reduce the need for fence and water infrastructure. Skilled herding can direct grazing to those portions of rangelands with higher forage production due to more rainfall, better soils, or previous light use while areas of low forage production can be rested, deferred, or lightly grazed. ${ }^{26}$ Although high cost and low availability of skilled herders has been a constraint, this may change if the economy stagnates from soaring energy costs, overwhelming debt, elevated interest rates, and rising food prices.

A promising new approach to improving livestock distribution and foraging efficiency in the future is virtual fencing. ${ }^{30}$ Virtual fencing employs audio and/or electrical stimulation to control animals. The use of virtual fencing to control when, where, and how livestock are fenced is discussed in detail by Anderson and associates. ${ }^{31}$

\section{Conclusion}

Rangelands in the 21st century will increasingly play a vital role in providing energy as well as livestock products, water, wildlife, and ecosystem services to people throughout the world ${ }^{26}$ Depletion of fossil fuels coupled with increasing human population will greatly increase the economic importance of rangelands, but degradation pressures on rangelands will probably also intensify in the United States and globally. Energy development may be the biggest rangeland degradation challenge US range managers will confront in the 21st century. By 2050 the US human population is projected to increase by $30 \%$ while a $40 \%$ population increase is expected worldwide. The easy-to-extract conventional reserves of oil and natural gas, which account for over $60 \%$ of world energy consumption, will have been severely depleted based on various projections. ${ }^{2,3,5,6}$ Lower-grade unconventional fossil fuels and renewable energy sources (wind, biomass, solar) that occur in large part on rangelands will need to be aggressively developed to avoid economic catastrophe. The eventual peaking of oil and natural gas production will require aggressive development of a combination of renewable and nonrenewable energy sources, including nuclear power. Some experts have advocated nuclear power as the solution to the world energy problem but it has several drawbacks including human safety, high cost of uranium, high water requirements, and hazardous waste disposal that limit its development.

Range livestock producers in the United States are benefitting from a major increase in world demand and prices for meat. Rapidly increasing demand for meat in several Asian countries with China at the forefront, large-scale conversion of productive rangelands into farmland in South America (Argentina, Brazil) and parts of Africa, and increasing frequency and severity of drought will probably cause meat prices to sharply increase from present levels. Rising meat prices will eventually result in more emphasis on livestock production from public rangelands. Conversely, the various risks (climatic, financial, biological, political) associated with ranching are all likely to increase. Higher annual variability in forage resources, higher production costs due to more expensive energy, and higher interest rates are major challenges that ranchers will confront in the near future. ${ }^{26}$ Selection of a sound stocking strategy, the appropriate grazing system, highly adapted livestock, and the most efficient combination of fence and watering points will be critical to individual rancher success. Although available knowledge is generally adequate for ranchers to make these selections, additional research could enhance decision-making in specific rangeland biomes. ${ }^{26}$

Public and political support for large-scale range improvement programs on both public and private rangelands may develop in response to rising meat prices and intensifying water shortage problems in the western United States. These programs oriented toward control of noxious plants, if properly designed and implemented, could increase employment, increase economic vitality, increase game animal populations, enhance ecosystem services, and reduce problems from wildfires as well as increase range livestock production. ${ }^{29,32}$

We believe managers must accept and prepare for the challenge of managing energy development on rangelands. Adding a class on "rangelands and energy" to undergraduate college curriculums now seems appropriate in terms of preparing future range professionals. Basic principles of grazing management such as control of intensity, distribution of animals, timing, frequency, and mix of animal species can be modified for energy development. We believe that, if well-planned and controlled, future energy developments on rangelands could have minimal adverse impact on most rangelands and may provide some important benefits. Some of the income ranchers, Native American tribes, and government agencies receive from oil and gas development can potentially be used to fi-

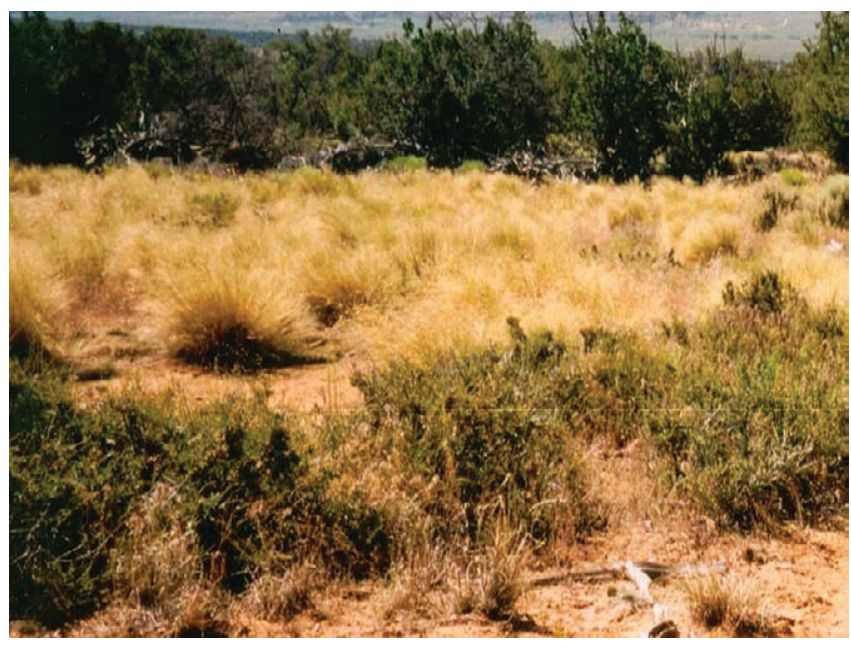

Figure 2. The site of a former oil well on rangeland in north-central New Mexico that has been revegetated by the rancher to provide high-quality habitat for mule deer and other wildlife. 
nance range improvements and enhancement of wildlife habitat. We know of ranchers who are now using this approach to both increase livestock forage and enhance wildlife habitat (Fig. 2). Decisions on placement and types of energy developments to permit on public lands will be critical in sustaining livestock grazing, watershed, wildlife, and esthetic values. A framework to systematically evaluate the impact of unconventional fossil fuel development on rangeland ecosystem services is provided by Kreuter and associates. ${ }^{33}$

In conclusion, our own biggest concern is not that shale oil and gas development will cause large-scale environmental damage to rangelands but rather that estimates of recoverable shale resources will turn out to be much too optimistic, causing a major economic crisis. For this reason we believe it important to aggressively develop alternative energy sources and implement energy conservation and efficiency improvements.

\section{References}

1. [USEIA] US Energy Information Administration. 2014. Annual energy outlook 2014. Washington, DC, USA: US Energy Information Administration. Report DOE/EIA-0383 (2014). 247 p.

2. USEIA. 2011. International energy outlook 2011. Washington, DC, USA: US Energy Information Administration. Report DOE/EIA 0484 (2011). 233 p.

3. Hughes, J. D. 2013. Drill, baby, drill. Santa Rosa, CA, USA: Post Carbon Institute. 166 p.

4. Heinberg, R. 2011. The end of growth. Gabriolas Island, BC, Canada: New Society Publishers. 321 p.

5. Aleklett, K. 2012. Peeking at peak oil. New York, NY, USA: Springer Books. $336 \mathrm{p}$.

6. Hall, C. A. S., and K. A. Klitgaard. 2012. Energy and the wealth of nations. New York, NY, USA: Springer Books. 407 p.

7. Rubin, J. 2012. The big flatline. New York, NY, USA: Palgrave Macmillan. 258 p.

8. Heinberg, R. 2005. The party's over. 2nd ed. Gabriola Island, BC, Canada: New Society Publishers. 306 p.

9. Heinberg, R. 2006. The oil depletion protocol. Gabriola Island, BC, Canada: New Society Publishers. 195 p.

10. Bryce, R. 2010. Power hungry. New York, NY, USA: Public Affairs Books. 394 p.

11. Leeb, S. 2009. Game over. New York, NY, USA: Grove Press. $245 \mathrm{p}$.

12. Kunstler, J. H. 2012. Too much magic. New York, NY, USA: Grove Press. 245 p.

13. Sreekumar, A. 2013. Just how expensive is shale oil? The Motley Fool (June 15, 2013). Available at: http://www.fool.com. Accessed 15 June 2013.

14. Gilbert, D., And T. Fowler. 2013. Exxon and Chevron miss out on oil boom. The Wall Street Journal (July 31, 2013). Available at: http://news.yahoo.com. Accessed 1 August 2013.

15. Crooks, E. 2014. Big oil counts the cost of tapping new discoveries. Financial Times (March 6, 2014). Available at: http:// www.euro2day.gr. Accessed 6 March 2014.
16. Amadeo, K. 2014. What's the forecast for oil prices? About Nerws. Available at: http://useconomy.about.com. Accessed 14 February 2014.

17. Smith, L. C. 2010. The world in 2050. New York, NY, USA: Dutton. 322 p.

18. Brown, L. F. 2012. Full planet, empty plates. New York, NY, USA: W. W. Norton \& Company. 144 p.

19. Powers, B. 2013. Cold, hungry and in the dark. Gabriola Island, BC, Canada: New Society Publishers. 312 p.

20. Heinberg, R. 2013. Snake oil. Santa Rosa, CA, USA: Post Carbon Institute. $151 \mathrm{p}$.

21. Nelder, C. 2011. The questionable economics of shale gas. Smart Planet (December 13, 2011) Available at: http://www. smartplanet.com.Accessed 14 December 2011.

22. Bateman, C. 21 June 2010. A colossal fracking mess. Vanity Fair. 1-4.

23. Kiger, P. J. 2014. Green fracking? 5 technologies for cleaner shale energy. National Geographic (March 19, 2014). Available at: http://news.nationalgeographic.com. Accessed 19 March 2014.

24. Morris, C. R. 3013. Comeback: America's new economic boom. New York, NY, USA: Public Affairs. 179 p.

25. Aвraham, S. 2010. Lights out. New York, NY, USA: St. Martin's Press. 254 p.

26. Holecheк, J. L. 2013. Global trends in population, energy use, and climate: Implications for policy development, rangelands management, and rangeland users. The Rangeland Journal 35:117-129.

27. McDonald, R. R., J. Fargione, J. Kiesecker, W. M. MillER, AND J. Powell. 2009. Energy sprawl or energy efficiency: climate policy impacts on natural habitat for United States of America. PLoS One v. 4(8): 1-11.

28. Hawkes, J. M., and J. Libbin. 2014. Cost and return estimates for New Mexico farmers and ranchers, 2002-2013. Available at: http://costsandreturns.nmsu.edu.

29. Holechek, J. L., R. D. Pieper, and C. H. Herbel. 2011. Range management: principles and practices. 6th ed. Upper Saddle River, NJ, USA: Prentice-Hall. 444 p.

30. Anderson, D. M. 2007. Virtual fencing-past, present and future. The Rangeland Journal 29:65-78.

31. Anderson, D. M., R. E. Estell, J. Holechek, S. Ivey, and G. B. Sмітн. 2014. Virtual herding for flexible livestock management. The Rangeland Journal 36:205-221.

32. Holecheк, J. L. 2007. Rangelands and national security. Rangelands 29(5):33-38.

33. Kreuter, U. P., W. B. Fox, J. A. Tanakzy, K. A. Macabo, D. W. McCollum, J. B. Mitchell, C. S. Duke, and L. Hidinger. 2012. Framework for comparing ecosystem impacts of developing unconventional energy resources on western rangelands. Rangeland Ecology \& Management 65:433-443.

Authors are Professor of Range Science, holechek@nmsu.edu (Holechek); and PhD and Research Senior (Sawalhab), Dept of Animal and Range Sciences, New Mexico State University, Las Cruces, NM 88003, USA. This paper was supported by the New Mexico State University Agricultural Experiment Station and was part of project 1-4-27652. 